\title{
Enhancing the Transparency of Student Merit System Using QR Code Technology: A Smart Campus Initiative
}

\author{
Muhammad Azhad Hilmi Muhammad Aiman Hilmi' ${ }^{1}$, Salfarina Abdullah², Sazly Anuar ${ }^{3}$, \\ Masnida Hussin ${ }^{4}$
}

\author{
${ }^{1,2}$ Department of Software Engineering and Information System, \\ Faculty of Computer Science andInformation Technology, UPM \\ ${ }^{3}$ Industrial Automation Section, Malaysia France Institute, University Kuala Lumpur \\ ${ }^{4}$ Department of Network and Communication Technology, \\ Faculty of Computer Science andInformation Technology, UPM \\ 11 azhad.hilmi@ gmail.com, ${ }^{2}$ salfarina@upm.edu.my, ${ }^{3}$ sazly@unikl.edu.my, ${ }^{4}$ masnida@upm.edu.my
}

Article History: Received: 10 November 2020; Revised: 12 January 2021; Accepted: 27 January 2021; Published online: 05 April 2021

\begin{abstract}
Technology has led to the utilization of information systems into human daily life activities. Computer systems have helped improve the modern human lifestyle by simplifying and facilitating activities from listening to music, grocery shopping to communicating with peoples across the world. Gearing up to smart campus initiatives, one of the issues to be tackled was the transparency in validating the student's attendance system used in many campuses and university events. The employment of technologies such as QR Code and facial recognition to validate the student's attendance certainly have helped in addressing this issue. In order to ensure the transparency of the existing manual student merit system used in the campus, this paper presents a solution known as CyberScan QR Code for Student Merit System that allows the students to obtain merits by scanning QR codes, as well as allowing student councils to provide merits for any events by generating QR codes. Students can keep track of their current total merit points and the events that they have previously attended so if there are any problems regarding their merits, they can always refer to their history of attended events as evidence. This paperless solution merit system also helps to reduce the usual time taken to calculate a huge amount of merits thus preventing from any miscalculation. Clearly, this initiative creates not just an efficient, transparent service but another greater experience for students to feel connected academically and socially.
\end{abstract}

Keywords:QR Code, Student merit system, transparency

\section{Introduction}

The student merit system is for university students to provide evidence of the students' attendance to events organized by the residential colleges, the faculty, clubs and the University itself. These merits are important for students to determine whether the amount of merits collected will earn them a spot to stay in residential colleges for the next session. This means that students will only secure a place for the next session in residential college if they have enough merits according to respective categories including residential college merits, faculty merits, club merits and university merits. The current student merit system is being implemented manually. Manually here refers to merits that are being printed by the student council of the residential college, faculty, clubs and the University. The merits are in the form of paper with the name of event printed on top of it, being cut into many pieces, distributed to the students who attended the event and finally pasted in the merit book. The merits however do not state the points of each merit. This is where the integrity issue being compromised.

In the recent years, the growing popularity of QR Code is not limited only to the automotive industry but also in other industries as well such as retail, FnB industry and in education where QR Code have been implemented as student's attendance system. This is because the QR Code has fastreadability and has greater storage capacity compared to standard barcodes. As for Cloud Computing, it has three characteristics which differentiates it from the traditional web hosting. It enables user to have as much or as little of service that they want at a particular time. It provides an easy and scalable to any computing resources and any IT services thus providing a more secured storage to store information as it does not involve any physical servers. The remainder sections present the related works, research methodology, results and discussions and finally a conclusion.

\section{Related Works}

Various smart campus initiatives have been widely embraced worldwide. Ranging from integration of digital technology into the learning process to assimilation of network computing technology, Wi-Fi and IoT in almost every campus activity, for the students academically and socially. Student merit system plays a big part in most university campuses. Merits are the students' security that determines their eligibility to stay in campus 
residential colleges. The more merits the student earned, the higher the possibility for staying. Thus, it is very crucial to make sure that the merit system is working efficiently and transparent.

Several past researches working on student merit system and student attendance system using QR Code were studied particularly on their main features. We selected five most prominent features a merit system should have and made them as basis for our evaluation and design decision. The features include 1) display event attended, 2) scan QR Code, 3) calculate and display total merit points, 4) generate QR Code to provide merit points, and 5) view total merit points and event attended. Table 1 below depicts our findings.

Table 1.Findings from past research works using QR Codes in attendance/merit system

\begin{tabular}{|c|c|c|c|c|c|c|}
\hline & $\begin{array}{c}\text { CyberScan QR } \\
\text { Code for } \\
\text { Student Merit } \\
\text { System }\end{array}$ & $\begin{array}{c}\text { Kolej Tun } \\
\text { Hussein Onn, } \\
\text { UKM E-Merit } \\
\text { System } \\
{[6]}\end{array}$ & $\begin{array}{c}\text { Students } \\
\text { Attendance } \\
\text { System } \\
\text { Using QR Code, } \\
\text { Applied Science } \\
\text { University, } \\
\text { Bahrain } \\
{[5]}\end{array}$ & $\begin{array}{c}\text { QR-Codes for } \\
\text { Attendance } \\
\text { Tracking } \\
\text { at Faculty of } \\
\text { Science, } \\
\text { Carleton } \\
\text { University, } \\
\text { Canada } \\
{[3]}\end{array}$ & $\begin{array}{c}\text { Attendance } \\
\text { Checking System } \\
\text { Using Quick } \\
\text { Response Code for } \\
\text { Students at the } \\
\text { University of } \\
\text { Sulaimaniyah, Iraq } \\
{[1]}\end{array}$ & $\begin{array}{c}\text { Putra VID } \\
\text { (PutraCome\& } \\
\text { Putra Merit) } \\
{[2]}\end{array}$ \\
\hline $\begin{array}{c}\text { Display event } \\
\text { attended }\end{array}$ & Yes & Yes & No & No & No & No \\
\hline $\begin{array}{c}\text { Scan QR } \\
\text { Code }\end{array}$ & Yes & No & Yes & Yes & Yes & Yes \\
\hline $\begin{array}{c}\text { Calculate } \\
\text { and display } \\
\text { total merit } \\
\text { points }\end{array}$ & Yes & Yes & No & No & No & Yes \\
\hline $\begin{array}{c}\text { Generate QR } \\
\text { code to } \\
\text { provide } \\
\text { merit points }\end{array}$ & Yes & No & $\begin{array}{c}\text { Yes (only } \\
\text { generate) }\end{array}$ & Yes (only generate) & Yes (only generate) & No \\
\hline $\begin{array}{c}\text { View total } \\
\text { merit points } \\
\text { and event } \\
\text { attended }\end{array}$ & Yes & No & No & No & No & No \\
\hline
\end{tabular}

There are not many systems focusing on student's merit that we managed to find except one used in Tun Hussein Onn College, UniversitiKebangsaan Malaysia, known as EMerit System. The other existing systems focused more on class attendance system using QR Code [6]. Using the QR code attendance system gives advanced features such as providing better security, maintenance of the system become easy and cost effective, generating quick statistical results, providing accurate and efficient data, and the system will be user friendly [4]. These are the reasons that drive the development of our student merit system which incorporates both event attendance system and student merit management system using QR Code.

\section{Design Diagram for Cyberscan Qr Code}

The design of CyberScan QR code for Student Merit System employs the QR Code technology to be used by the student to obtain the merit points collected for the event that he/she attended without any required external devices. The student just has to install/download the system and scan the QR code generated by the student council. This section presents the design diagrams for this system. 


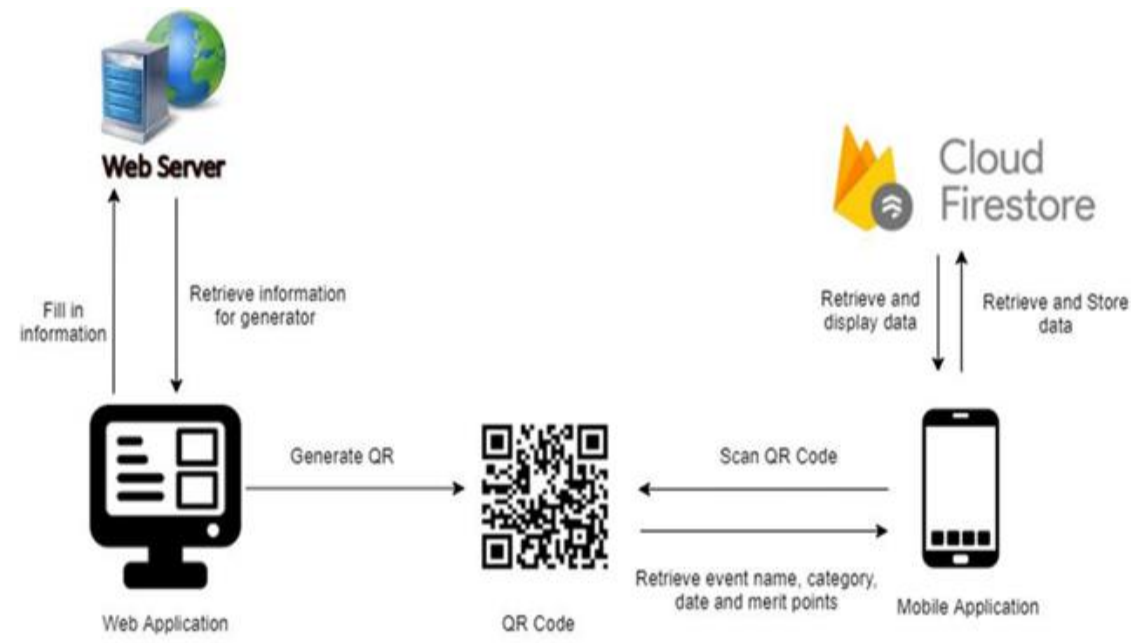

Figure 1.System design for CyberScan QR Code for Student Merit System

Student: Student is able to login the system by entering email and Password. After login,student will be directed to their Profile page and is allowed to can scan the generated QR Code and a popup will be displayed after scanning process has completed.

Student council: Student council is able to generate QR Code by filling in the requiredinformation whichare the event name, event category, date and the merit points allocated for the event. Student council will display the generated QR Code for the students to scan using their mobile application whenever they attend an event.

Student information: The student council is able to access the database where it stores allthe information regarding the student such as their full name, their email address, their Matric Id, the merit points that they have collected according to respective categories and the list of events that they have attended.

Update data: Whenever the student scans the QR Code, the data retrieved from the QRCode will be automatically updated in the database hence providing a real time database forthe student council and also for the students to make sure that their merit points are being updated.

\subsection{Use case diagram}

The use case diagram consists of elements that represent whole system which are the actor and use cases which represents the functional requirements of the system. Figure 2 describes Use case diagram for the introduced system.

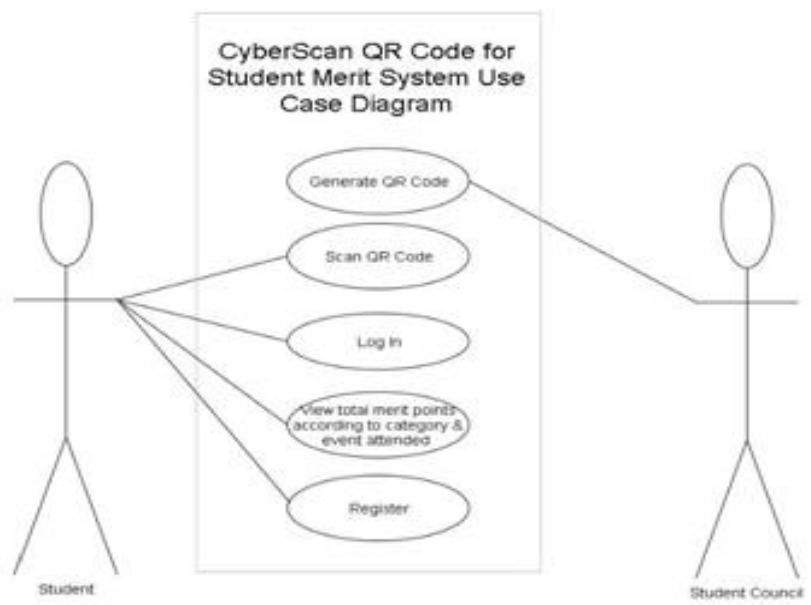

Figure 2.Use case diagram for CyberScan QR Code for Student Merit System 


\section{Implementation and Results}

\subsection{User Interfaces (UI) of CyberScan QR Code for Student Merit System for Mobile Client}

The mobile client for this system is operated on Android device. In order to use it, the application has to be installed on a device. The following are the user interfaces of the system that will be experienced by the users.

Table 2.UI for CyberScan QR Code for Student Merit System

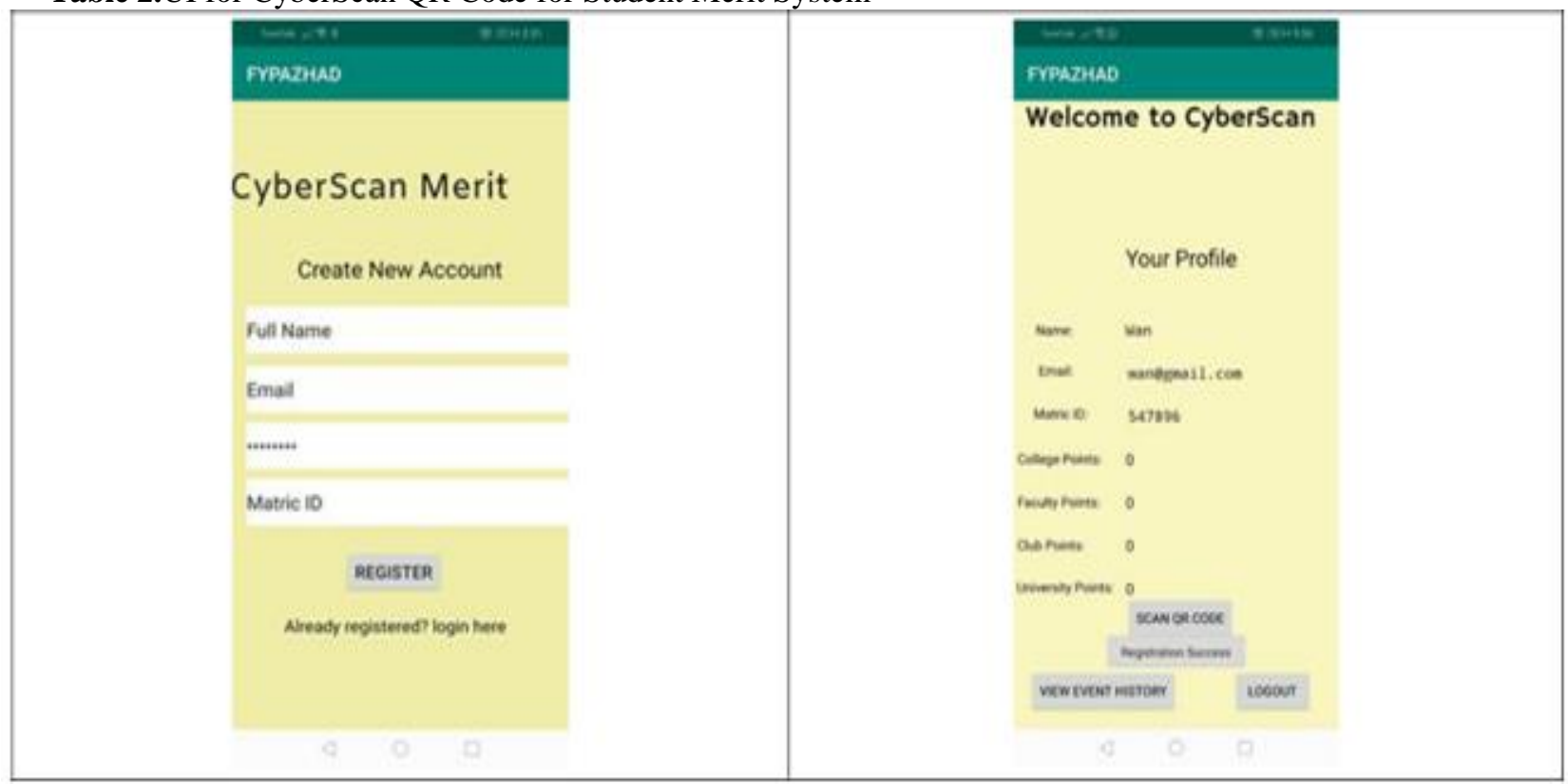

1.Registration form for first time users

2. Successful Registration

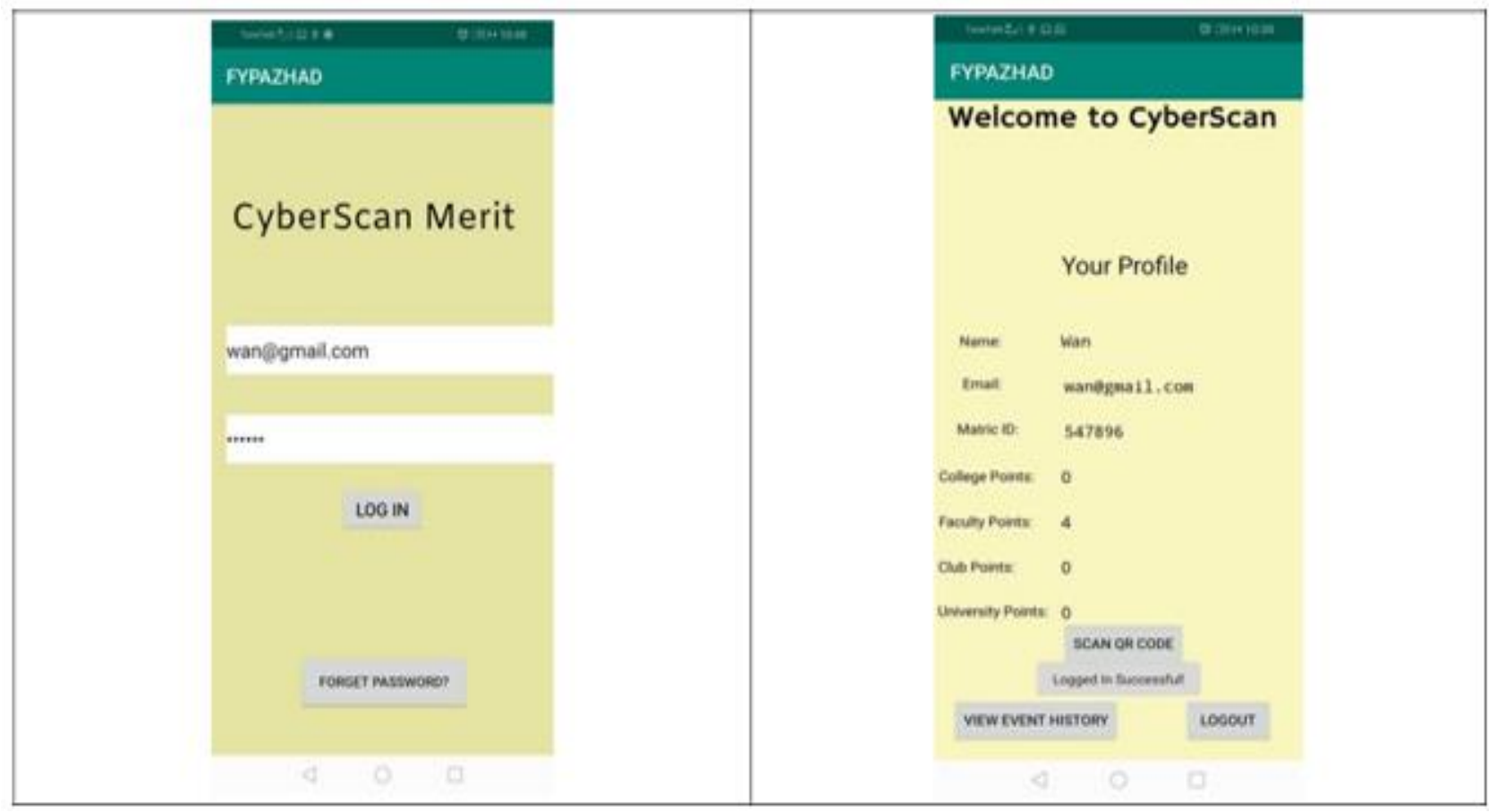

3.Log in form with sample email and password

4. Log in successful message 


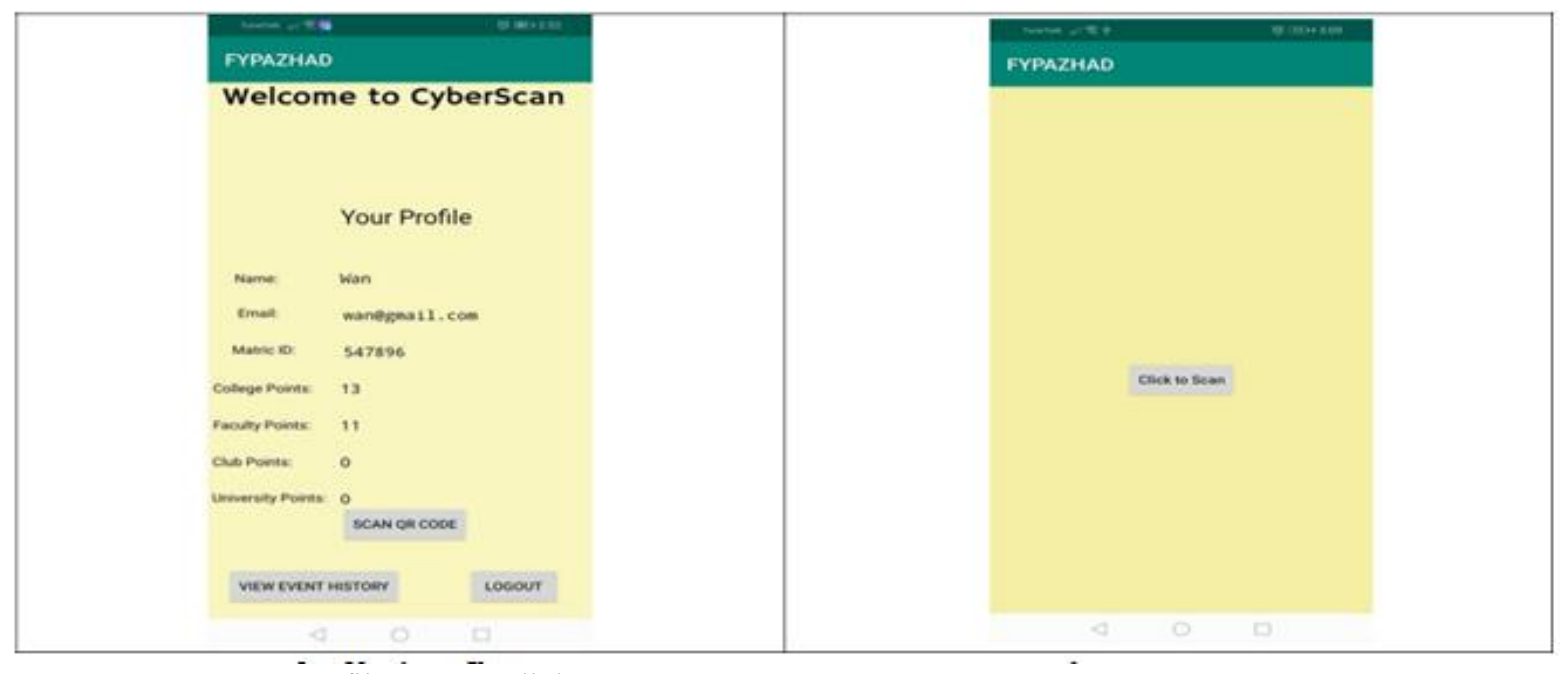

5. User's profile page $\overline{6}$. Click to scan page

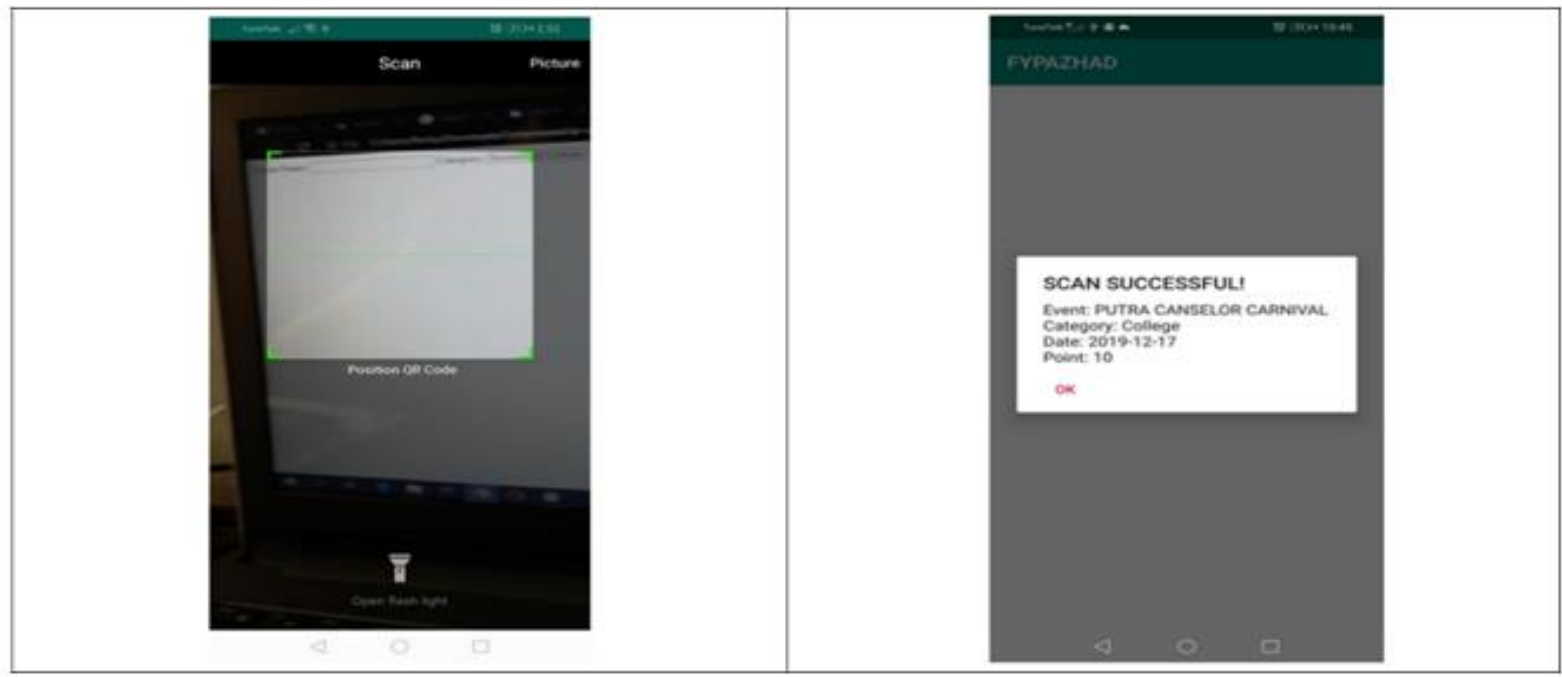

7. Scan QR code page message

8. Successful scan QR Code popup

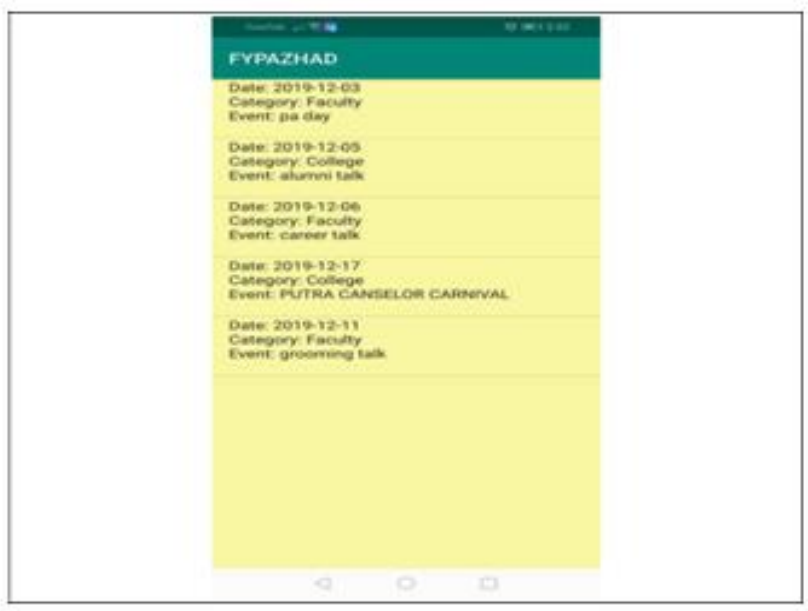

9.View Event History page

\section{Conclusion}

The CyberScan QR Code for Student Merit System is developed as a solution that enhances and improves the current manual student merit system. Its development takes into consideration many factors to ensure that it will not only solves the issue of time consumption and lacking of transparency but also serves the students more 
efficiently and supports smart campus way of living. It had undergone the testing phase and passed both functional and integration testing. Nevertheless, suggestions for future improvement includes improving the user interface for both the mobile and web client, and also the speed of system performance.

\section{References}

1. Baban, M. H. M. 2014. Attendance checking system using quick response code for students at the university of Sulaimaniyah. Journal of Mathematics and Computer Science, 10, 189-198.

2. Daud, M.F. 2019. UPM Putra Virtual ID (PutraVID) [online] Available at: https://idec.upm.edu.my/upload/dokumen/20190807161116UPM_Putra_Virtual_ID_(Putra VID)

3. Deugo, D. 2015. Using qr-codes for attendance tracking. In Proceedings of the International Conference on Frontiers in Education: Computer Science and Computer Engineering (FECS)The Steering Committee of The World Congress in Computer Science, Computer Engineering and Applied Computing (WorldComp), 267.

4. Elbehiery, H. 2019. Enhancement of QR code Student's Attendance Management System using GPS. IOSR Journal of Computer Engineering (IOSR-JCE), 21(4), 18-30.

5. Masalha, F., \&Hirzallah, N. 2014. A students attendance system using QR code. International Journal of Advanced Computer Science and Applications, 5(3), 75-79.

6. Othman, N. K., Saidi, Z. A., Sino, H., Koh, K. Wei., Wan Shukri, \& W. M. H. 2018. Tinjauan Awal Pembangunan Sistem e-Merit: PenilaianAlternatifPenglibatanPenghuniKolejTun Hussein Onn. ProsidingKonvensyenKepengetuaandanFeloPenghuniKolejKediaman Universiti Awam Kebangsaan $2018,24$. 